\title{
新規澱粉グラフト紙力剤について*
}

\author{
星光化学工業株式会社 研究開発本部開発 1 部 馬 場 勇 治
}

\section{New Paper Strength Agent from Grafted Starch}

\section{Yuji Baba}

Research \& Development Division. Seiko Chemical Industries Co.. Ltd.

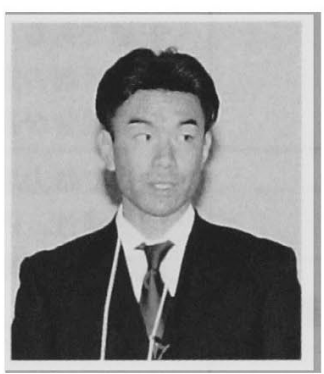

In paper making process. Starches and Polyacrylamides (PAM) are widely used as paper strength agent. Various kinds of PAM have been effectively utilized, particularly in Japanese paper industry.

In this paper, we introduce newly developed hybrid type of paper strength agents, which have both features of Starch and PAM. The hybrid agents composed of PAM grafted starch show excellent paper strengthening effect in wide $\mathrm{pH}$ range up to neutral with reduced alum usage. The hybrid agents can give enhanced strength for both dry and wet sheet and also can improve convertability of paper sheet.

In addition,the hybrid agents can improve cost performance and environmental load in paper making process.

分類： $W_{6}$ 紙力增強剤, $Y_{5}$ 高分子化学

\section{1.はじめに}

浅粉類は製紙用の紙力増強郕として, 古くから用い られてきた。内添用の紙力郕としては,カチオン変性 された激粉が主として用いられ，表面染工用の表面紙 力, 印刷適性向上剂としては, 酸化海粉が主として用 いられている。

瑖粉は植物が水と空気とを原料として, 太陽エネル ギーにより作り出すものであり，その意味では再生可 能な資源であり，生分解性に優れ，生物にとって安全 な物質である。また，経済面においても，激粉は現在 最も安価な農業製品のひとつである。

一方, 合成ポリマー系紙力剤は 1960 年代の ACC 社の開発に端を発し, 石油化学製品のアクリルアミド

*平成 12 年度年次大会講演（講演 No. C 14）
系の紙力率が広範囲に用いられてきた。

当初は硫酸バンドを定着助片とする，アニオン変性 品が主体であったが, カチオン変性, 两イオン変性の 製品が開発され，高 $\mathrm{pH}$ 抄造にも対応できるようにな ク,さらに使用範囲が広がってきた。近年, 製紙業界 では, 両イオン性で架橋タイプのポリアクリルアミド 系紙力剤が「共重合紙力片」と称され, 内添用紙力剤 の主流になりつつある。表 1 に澱粉系紙力剤とポリア クリルアミド (PAM) 系紙力剛の比較をまとめる。

当社においては, 澱粉, ポリマーの雨者の長所を兼

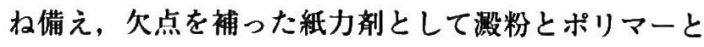
のグラフト紙力剤の開発に力を入れ製品群を上市して きた。

グラフトとは接ぎ木を意味する言葉であり, 文字通 り幹となるポリマーに枝となるポリマーを接ぎ木した 構造をとると考えられる(図 1)。 
表 1 内添用紙力剤の比較

\begin{tabular}{|c|c|c|}
\hline & 長 所 & 短 \\
\hline 澱粉系紙力剂 & 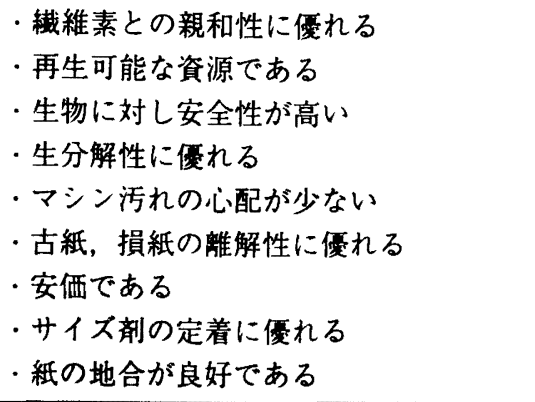 & $\begin{array}{l}\text { ·同一添加量での比較において紙力の増強効果 } \\
\text { が弱い } \\
\text { ·使用量が多いと廃水負荷を高める }\end{array}$ \\
\hline PAM 系紙力䇌 & $\begin{array}{l}\text { ·少量で紙力增強効果が大きい } \\
\text { ·印刷適性, 内部強度增強効果が大きい } \\
\text { ·紙の固さ (剛度) 増強効果に優れる }\end{array}$ & $\begin{array}{l}\text { ·限りある石油資源に依存している } \\
\text { ·マシンを污す頃向が強い } \\
\text { ·高価である } \\
\text { ·損紙, 古紙の離解性に劣る } \\
\text { ·紙が固くなり過ぎ, 加工性に劣る場合がある } \\
\cdot \text { モノマーには毒性がある } \\
\text { ·生分解性に劣る }\end{array}$ \\
\hline
\end{tabular}

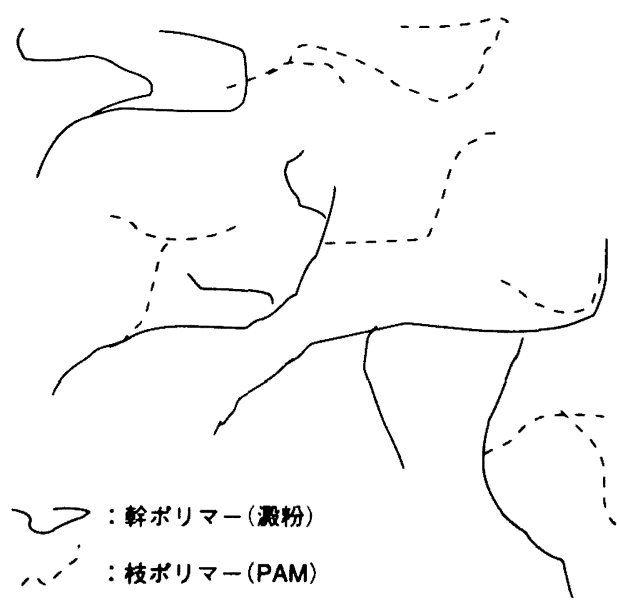

図 1 没粉グラフト紙力郕モデル
得られたグラフトポリマーは枝ポリマーの性状をか なり強く表すが, 幹ポリマーの性質もある程度受け継 ぐと考えられる。この点は, 樹木の接ぎ木とよく相似 している。

従来の筑粉グラフト紙力剤は糊液の老化という激粉 の持つ欠点を払拭し切れず，高濃度の製品を得ること が困難であった。新規グラフト紙力片は原料澱粉の変 性により，この点を解決したものである。

\section{2. 新規筑粉グラフト紙力骭 フィクスター AGB, CGB について}

本報告では，溊粉クラフト紙力剤として，アニオン タイプのフィクスター AGB と，カチオンタイプの イクスターCGBについて，製紙用紙力郕としての効 果について報告する（表 2）。

表 2 新規汼粉グラフト紙力剤の性状

\begin{tabular}{c|c|c}
\hline & フィクスター AGB & フィクスター CGB \\
\hline 外観 & 淡黄色半透明粘液 & 淡黄色半透明粘液 \\
\hline イオン性 & アニオン & カチオン \\
\hline 渾度 & $15 \%$ & $15 \%$ \\
\hline 粘度 & $3,000 \sim 10,000 \mathrm{cps}$ & $3,000 \sim 10,000 \mathrm{cps}$ \\
\hline $\mathrm{pH}$ & $4 \sim 5$ & $3 \sim 4$ \\
\hline
\end{tabular}




\section{3. フィクスターAGB の内添試験評価}

3.1 酸性上質紙条件でのアニオン性 PAM との 効果比較試験

試験条件

・パ ル プ: L-BKP $\mathrm{CSF}=450 \mathrm{~mL}$

・抄紙米坪量 : $60 \mathrm{~g} / \mathrm{m}^{2}$

・硫酸バンド：0.5\%, 0.75\%,1.0\%, $1.8 \%$ (対パ ルプ）（抄紙 $\mathrm{pH}$ は 4.5 に硫酸で調 整)

・剂：アニオン性 PAM（A-PAM） $0.5 \%$ (対パルプ)

AGB $0.5 \%$ （対パルブ）

・サイズ剤：ロジンエマルジョンサイズ剤 $0.3 \%$

(対パルプ)

アニオン性 PAM 紙力剤は充分な紙力增強効果を得 るのに多くの硫酸バンド量を必要とするが，AGBは 少量の碳酸バンドでその効果を発揮する（図2）。

アニオン性 PAM は硫酸バンド量が少ないとサイズ 効果の低下をきたすが，AGBでは硫酸バンド量が少 なくても安定したサイズ効果を発揮する（図 3)。

3.2 上筫抄合わせ纸における効果試験

\section{試験条件}

・パ ル プ:L-BKP : N-BKP $=1: 1$

$$
\mathrm{CSF}=400 \mathrm{~mL}
$$

・抄秪米坪量 $: 80 \mathrm{~g} / \mathrm{m}^{2} \times 2$ 枚の抄合わせ

・硫酸バンド $: 1.0 \%, 1.9 \%$ (対パルプ）

$$
(\mathrm{kg} \cdot \mathrm{cm})
$$

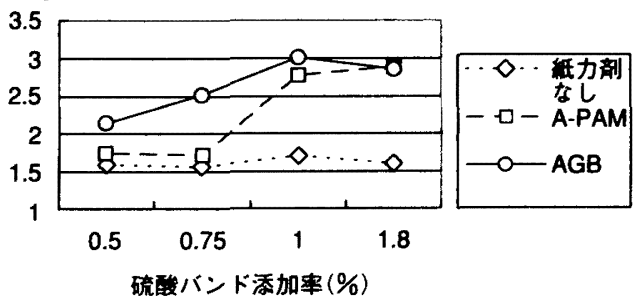

図 2 内部強度

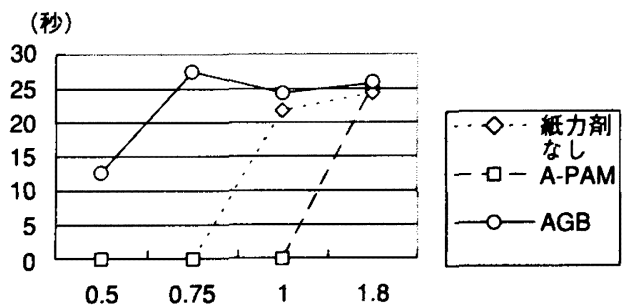

硫酸バンド添加率(\%)

図 3 ステキヒトサイス度
・紙 力 剤：アニオン性 PAM（A-PAM） $0.5 \%$ （対パルプ）

$$
\text { AGB } \quad 0.5 \% \text { (対パルプ) }
$$

・サイズ剤：ロジンエマルジョンサイズ剤 $0.5 \%$ （対パルプ）

AGB はアニオン性PAMに比べ，少ない硫酸バン ド量, 高 $\mathrm{pH}$ で効果が優れ，準中性抄造に適している ことがわかる（図 4，5，6）。

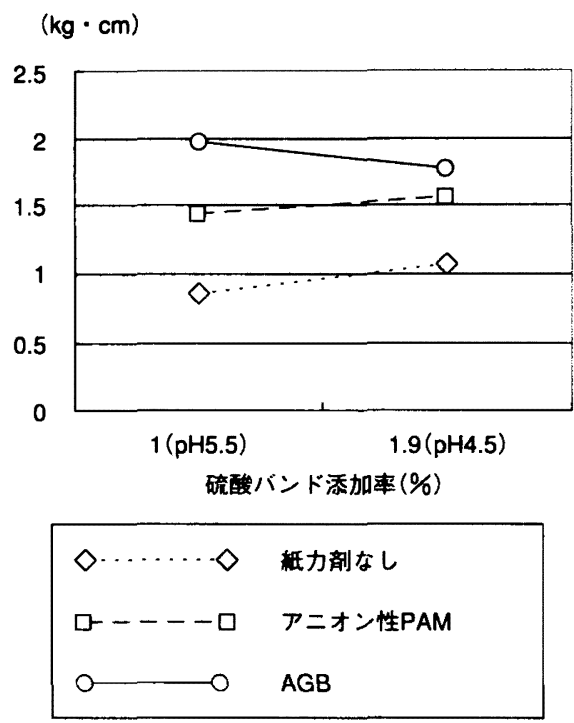

図 4 層間強度

(秒)

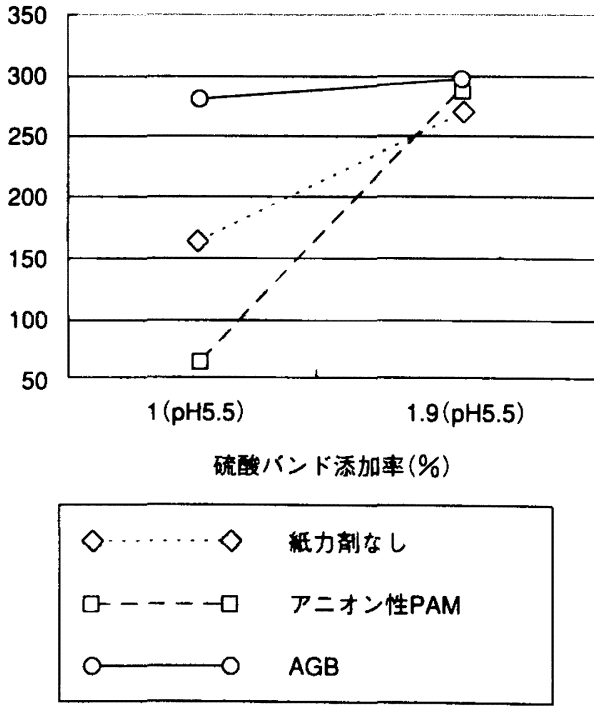

図 5 ステキヒトサイズ度 
(回)

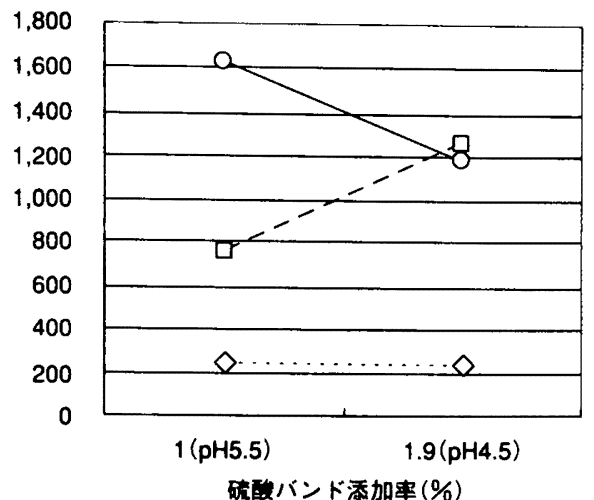

\begin{tabular}{|ll|}
\hline$\cdots \cdots \cdots \cdots \diamond$ & 竝力詴なし \\
$\square----ロ$ & アニオン性PAM \\
$0-0$ & AGB \\
\hline
\end{tabular}

図 6 耐折強度

\section{3 カチオン性湿洞紙力剤との併用効果}

\section{試験条件}

・パ ル プ: L-BKP $\mathrm{CSF}=400 \mathrm{~mL}$

・抄秖米坪量：60 g/m

・紙 力 剂：カチオン性湿閏紙力剂 $1.0 \%$

(対パルプ)

アニオン性 PAM（A-PAM）

$0.2 \%, 0.4 \%, 0.6 \%, 0.8 \%$ （対 パル゚)

AGB $0.2 \%, 0.4 \%, 0.6 \%, 0.8 \%$ (対パルプ)

AGB はアニオン性PAM の場合のように併用比事 に制限を受けず, 湿潤強度紙力郕と併用して, 乾湿強 度を大幅に向上させる（図 7,8）。

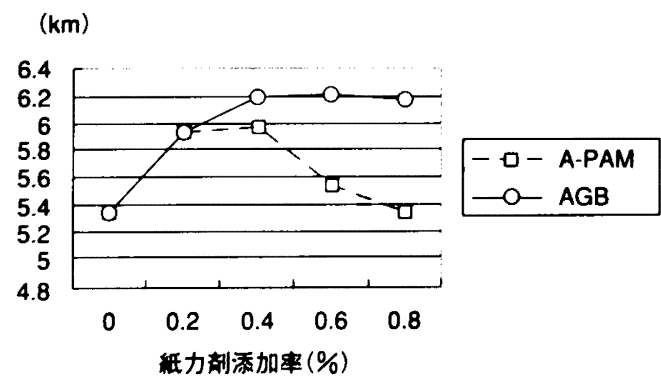

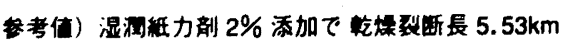
図 7 乾嬠裂断長 (km)

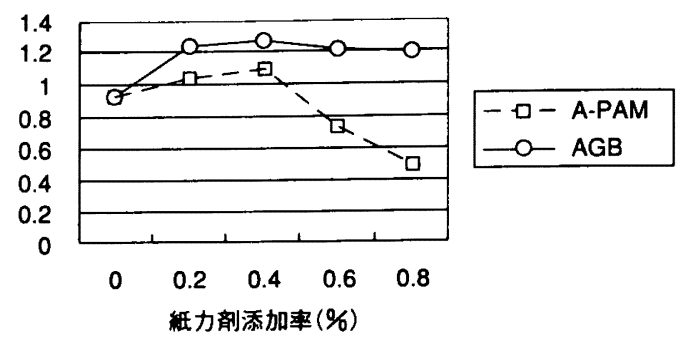

考值）湿㴸紙力剂 $2 \%$ 添加で 湿潤裂断長 $1.10 \mathrm{~km}$

图 8 浸潤断裂長

3.4 ホフマン系紙力剤との併用効果 試験条件

・パ ル プ:段ボール古紙/雑古紙 $=95 / 5$

$\mathrm{CSF}=400 \mathrm{~mL}$

- 抄紙米坪量: $150 \mathrm{~g} / \mathrm{m}^{2}$

・硫酸バンド：1.0\%（対パルプ）

・紙 力 剤: アニオン性PAM (A-PAM)

$0.15 \%, 0.5 \%$ (対パルプ)

AGB 0.15\%，0.5\%（対パルプ）

ホフマン系紙力剤 $0.15 \%, 0.5 \%$

(対ハルプ)

AGB はホフマン系紙力殽との併用効果がアニオン 性 PAM に比べ優れている。さらに，加熱により紙中 水分を少なくした場合の紙力效果も優れている結果も あり，ライナー，中芯原紙における熱加工時の割れ対 策としても期待できる（図 9，10，11，12）。図中の 紙力添加种はアニオン性 PAM あるいは AGB とホフ マン系紙力剤を 1：1の割合で併用添加。

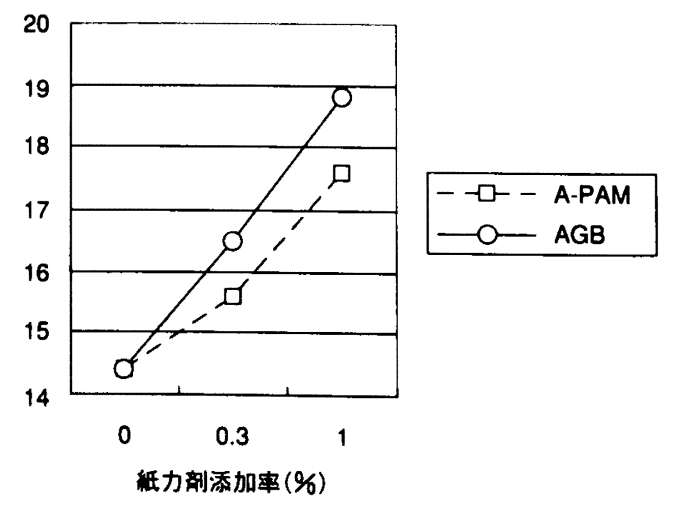

図 9 比圧縮強度 


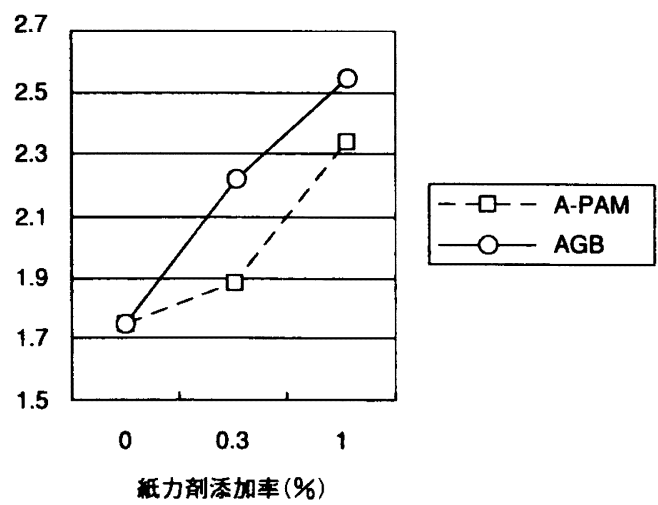

図 10 比破裂强度

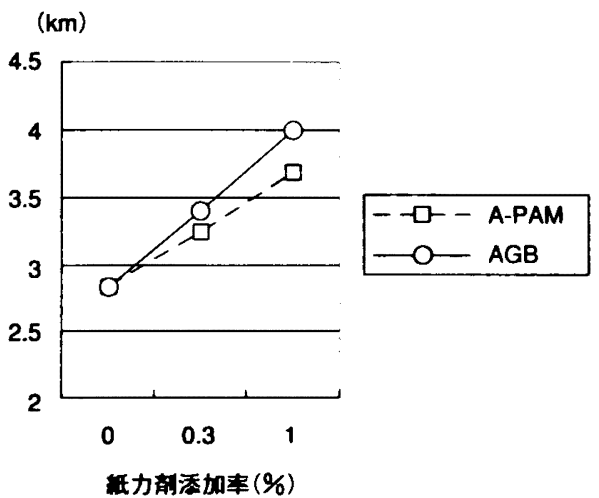

図 11 裂断長

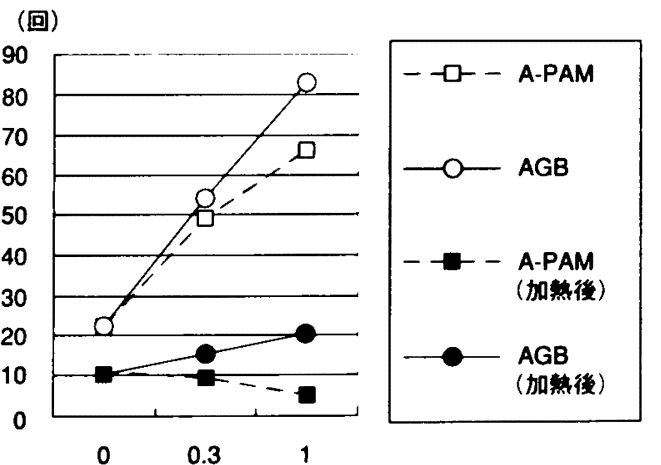

纸力剂添加率 $(\%)$

図 12 预折强度

4. フィクスターCGB の内添試釦評価

\section{1 カチオン䈣粉及び中性抄紙用両性 PAM との効果比較試験}

試験条件

・パ ル プ:L-BKP CSF $=350 \mathrm{~mL}$

・抄紙米坪量 $: 60 \mathrm{~g} / \mathrm{m}^{2}$

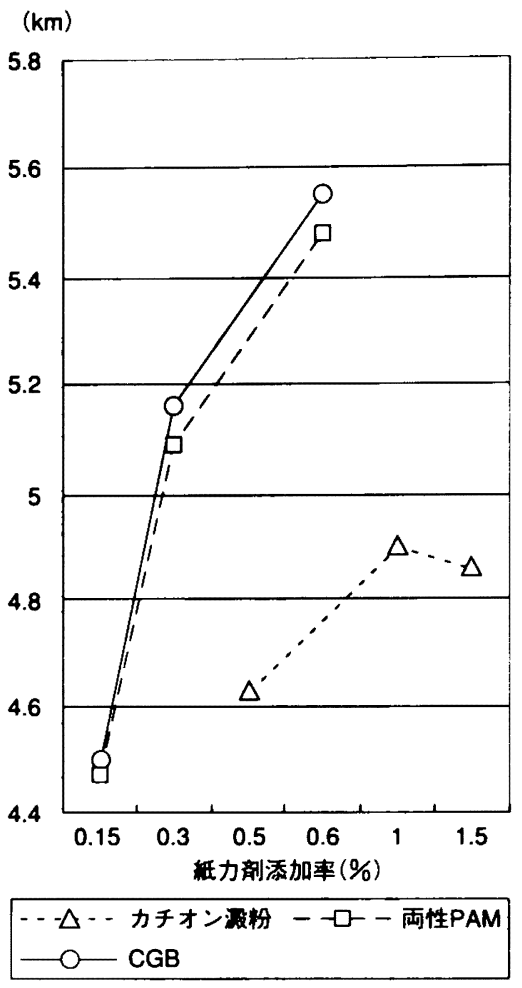

図 13 裂断長

・軽質炭酸カルシウム：0.6\%（対パルブ）

・紙 力 郕：カチオン泚粉 $0.5 \%, 1.0 \%, 1.5 \%$ (対パルプ)

而性 PAM 0.15\%, $0.3 \%, 0.6 \%$ (対パルブ)

CGB 0.15\%，0.3\%，0.6\%（対パル プ)

CGB は特に紙の内部强度において，西性 PAM を 凌ぐ効果が得られた（図 13，14）。

4.2 アルカリ抄造における填料步留効果 試倹条件

・パ ル プ:L-BKP $\mathrm{CSF}=350 \mathrm{~mL}$

一抄紙米坪量 $: 60 \mathrm{~g} / \mathrm{m}^{2}$

・軽倎炭酸カルシウム：20\%（対パルプ）

・秖 力 郕：カチオン澱粉 $0.75 \%, 1.0 \%$ （対パルブ）

两性 PAM 0.25\%，0.35\%

(対バルプ)

CGB $0.25 \%, 0.35 \%$

（対パルプ）

・歩 留 郕：コロイタルシリカ $0.1 \%$

結果を図 15 に示す。 
$(\mathrm{kg} \cdot \mathrm{cm})$

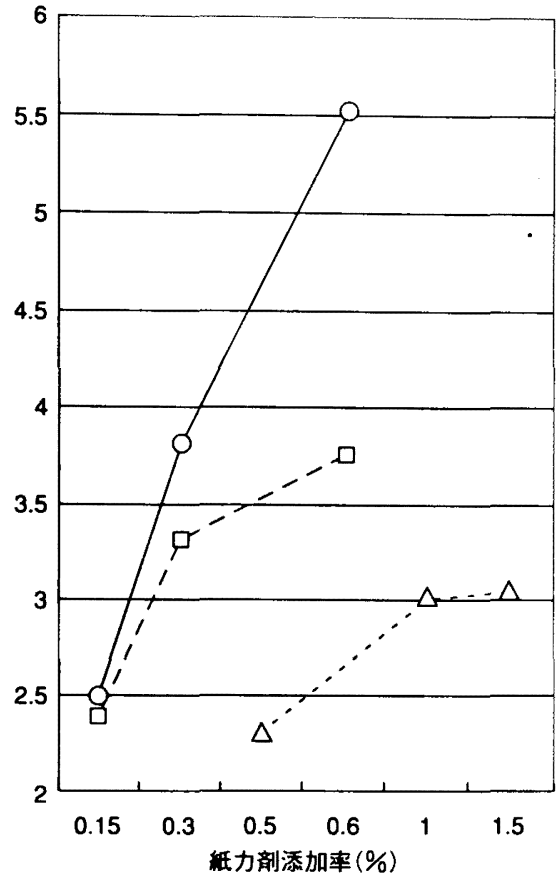

- - - - カチオン澉粉 - -

図 14 内部強度

\section{5. その他，瑖粉グラフト紙力剤の特性}

各所におけるマシン抄造試験の結果，下記のような 特性が認められている。

A. 抄紙工程

・紙力棛に起因するマシン污れが少ない。

・損紙、耳部の離解性がよく、未離解によるトラフ ルの発生を軽減する。

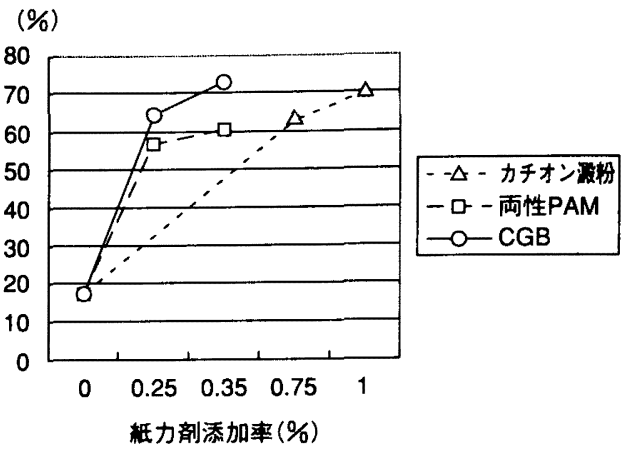

図 15 填料歩留効果

・良好な地合を形成する。

・ドライヤーの離型性が良い。

・ブレスの㩁水性が良い。

B. 成紙特性

・引裂強度の低下が少ない。

・湿度低下による成紙水分の減少を抑える。

・紙の伸び強度が改善される。

・成紙の縦横強度の差が圧縮される。

・密度の上昇を抑える。

・紙にソフト感を与える。

C. 加工工程

・過乾燥下で紙の折れ割れの防止効果がある。

・摩擦係数が上昇する。

・ポリラミ接着性が向上する。

・インキ接着性が向上する。

6. おわりに

新规淑粉クラフト紙力剂は, PAM 系紙力剂と澱粉 系紙力剤の特長を兼ね備えた紙力剤であり，環境に優 しいハイフリット紙力剤として, 今後の展開が期待さ れる。 


\title{
顔料塗工紙のピッキング現象の解析（第 2 報） \\ 一ラテックスとデンプンの強度発現機構の相違点についてー
}

\author{
日本エイアンドエル株式会社 ラテックス研究所 西岡 利恭
}

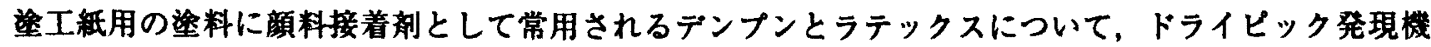
構の相違を明らかにするため、基砥的検討を行った。バインダーとしてデンプンのみを用いたモデル染

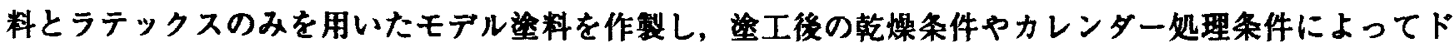
ライピック強度がどう変化するかを調べた。

塗工紙作製条件によるドライピック強度の変化を理解するために，乾嬠初期のパインターーマイグレー ションによって変化する巨視的バインター効事 $\beta$ とその啳の乾燥負荷やカレンダー处理によって変化す る微視的バインター効率 $a$ の概念を运入した。

デンプンのみ用いた望料の場合，バインターマイグレーションによる巨視的バインター効率 $\beta$ の変 化でドライビック強度も大きく変化したが, 微視的バインター効率 $a$ が変化しないため乾婐負荷やカレ ンター処理条件が大きく変化してもドライピック強度は殆ど変化しなかった。

一方, ラテックスのみを用いた淕料の場合, 乾嬠条件を変えても巨視的バインター効率 $\beta$ と微視的バ インター効率 $a$ は殆ど変化せず, 安定したドライピック強度を示した。

一般的なデンフンとラテックスの併用系染料では, マイクレーションによってドライピック強度が変 化した場合はデンブンが, カレンター処理条件によりドライピック強度が変化した場合はラテックスが それぞれ関与していると考えられ, ラテックスとデンフンの強度発現機構についての基本的な相違点が 明らかになった。

(本文 1 ページ)

\section{新規晸粉グラフト紙力剤について}

\section{星光化学工莱株式会社 研究䦕発本部開発 1 部 馬場 勇治}

製紙業界においては，滥枌類やポリアクリルアミド（PAM）が，紙力増強剂として広く用いられて

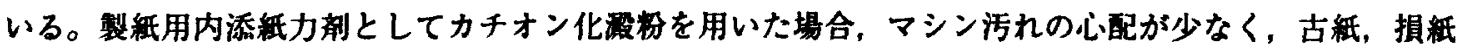
の觹解性に優れ，多く用いても製品原価への負担が少なく，また，環境面で安全な紙製品が得られる点 が長所として挙げられる。

PAM 系紙力剂は少量添加で的に紙力を增強する奻果があり，印刷適性，内部強度增強効果に侵れ ており，紙の固さを向上する効果にも優れており，特に，日本においては数種類の PAM 系紙力夙が製 纸工程で有効に使用されている。

我々は，没粉と PAM 系紙力郕の特徵を併せ持つハイブリッドタイプ紙力增強剂を開発した。

この新しい紙力增強剂は，没粉と PAM 系紙力剂のグラフトポリマーからなり，経済性に優れ、環境 に優しく，成紙に高い乾燥と湿洞の紙力と加工嗃性を与え，中性域までの広い $\mathrm{pH}$ 城で传れた効果を発 揮する。本報では，激舩一ポリマークラフト紙力唷の特性とその応用分野についての概略を紹介する。

(本文 11 ベージ) 